\title{
PENCIPTAAN FOTOGRAFI SUREALISME HUMAN AND TIME
}

\author{
Marventyo Amala \\ Mahasiswa Program Studi Penciptaan Fotografi \\ Program Pascasarjana ISI Yogyakarta, Jalan Suryodiningratan No. 8, Yogyakarta \\ No. Tlp. (0274) 419791, No. Hp.: 08085755903438 \\ E-mail: marvenytoamala@gmail.com
}

\begin{abstract}
Abstrak
Waktu adalah sebuah konsep yang sepenuhnya tergantung pada persepsi manusia. Waktu adalah sebuah konsep yang tergantung pada kejadian-kejadian yang dapat diperbandingkan dengan apa yang dialami. Seseorang, bahkan setiap manusia tidak bisa terlepas dari entitas waktu ini. Sekuat apa pun ingin melepaskan diri, manusia tidak akan pernah lepas dari "sang" waktu, bahkan saat mati pun masih dilingkupi oleh waktu. Berlandaskan pada konsep tentang waktu, maka terbesit sebuah ide mengenai penciptaan fotografi dengan tema waktu yang bergaya surealis. Karakteristik karya fotografi ini lebih menekankan pemotretan subjek manusia dibalut dengan kain putih sebagai representasi waktu. Unsur pencahayaan menjadi hal yang sangat diperhatikan agar ekpresi dari subjek dapat terekam dengan baik. Sementara itu, sifat momen, pilihan arah cahaya, dan eksplorasi dengan menggunakan teknik multiple exposure, menjadi bagian yang juga ditekankan pada karya ini.
\end{abstract}

Kata kunci: fotografi, surealisme, waktu

\begin{abstract}
The Creation of Surrealism Photography: Human and Time. Time is a concept that is entirely dependent on human perception. Time is a concept that depends on events that can be compared with what happened. Someone, even every man cannot be separated from the entity of time. No matter how someone wants to get away, he would never be separated from "his" time, even death is still surrounded by time. Based on the concept of time, then an idea about the creation of photography with the theme of time and surrealist styles popped up. The characteristis of this photography project emphasizes on shooting human subjects wrapped in a white cloth as a representation of time. Lighting element is very highly considered to show the expressions of the subject that it could be recorded properly. In the meanwhile, the moment, the choice of light direction, and exploration using multiple exposure technique, are essential parts of this work.
\end{abstract}

Keywords : photography, surrealism, time

\section{PENDAHULUAN}

Manusia bahkan semua yang diciptakan oleh Tuhan terlingkupi oleh waktu. Waktu merupakan keniscayaan bagi setiap makhluk hidup. Dengan adanya waktu, manusia ada dan berpikir bahwa sedang berada pada saat ini. Hal tersebut dikuatkan oleh pandangan fisikawan terkenal bernama Julian Barbour.
Ia mendefinisikan waktu sebagai potonganpotongan informasi yang tersimpan di memori dalam otak. Andaikata seseorang tidak punya memori, orang itu akan hidup hanya pada saat ini saja; otaknya tak akan mampu membuat intepretasi-intepretasi ini dan, dengan demikian, dia tidak akan memiliki persepsi apa pun tentang waktu (Yahya 2005:139). 
Jadi, manusia menganggap waktu itu adalah sebagai masa lalu, masa sekarang, dan masa depan. Waktu adalah sebuah persepsi manusia dalam menjalani kehidupan. Waktu tidaklah bersifat mutlak; ia adalah konsep subjektif yang ditangkap dan dirasakan beragam, tergantung dari peristiwa-peristiwa yang dialami manusia.

Fotografi berkembang sebagai dunia teknologi tersendiri dan teknologi fotografi telah mengubah wajah dunia menjadi dunia gambar. Perkembangan fotografi juga telah memberikan berbagai kemungkinan "kultural" bagi manusia untuk menciptakan bentuk seni yang tidak mungkin dilakukan sebelumnya. Fotografi mulai bergeser ke arah seni karena fotografi menjadi suatu wahana ekspresi dalam seni karena dapat sebagai wujud emosi dan refleksi realitas sebenarnya, bahkan fotografi memiliki nilai lebih dalam kemampuannya untuk "membekukan momen" dengan nilai realisme dan presisinya yang tinggi sehingga didayagunakan sebagai "alat bantu" untuk menciptakan karya seni (Soedjono, 1999:53). Jenis gaya dan aliran yang begitu banyak dalam fotografi akan mencerminkan pribadi fotografernya. Akan tetapi, bukan itu yang menghentikan fotografi untuk diakui sebagai seni. Ada titik kesetaraan antara keduanya, yaitu apa yang dilakukan perupa dan fotografer, bahwa keduanya menciptakan karya yang berasal dari ekspresi pembuatnya yang terdapat di dalam karya mereka. Sekali lagi bukan dari proses pembuatan karya tersebuat yang membuat sebuah karya tersebut bersifat seni atau tidak, melainkan adanya makna, ungkapan jiwa dalam sebuah karya.

\section{Dalam buku Pot-Pourri dijelaskan} bahwa:

Fotografi ekspresi adalah sebuah karya fotografi yang dirancang dengan konsep tertentu dengan memilih objek foto yang terpilih dan yang diproses dan dihadirkan bagi kepentingan si pemotretnya dengan luapan ekspresi artistikdirinya.Makakarya tersebut bisa menjadi sebuah karya fotogtafi ekspresi. Dalam hal ini karya fotografi ekspresi dapat dimaknakan se b a ga i suatu medium ekspresi yang menampilkan jati diri fotografi seni. Karya fotografi yang diciptakannya lebih merupakan karya seni murni fotografi (fine art photography) karena bentuk penampilannya yang menitik beratkan pada nilai estetis seni itu sendiri (Soedjono, 2006:27).

Dari kutipan tersebut, tampak bahwa fotografi ekspresi merupakan ungkapan jiwa yang mengutamakan ekspresi jati diri pribadi seseorang yang diekspresikan menjadi karya seni. Penulis mengekspresikannya dalam bentuk karya fotografi ekspresi dengan subject matter manusia yang dieksplorasi dengan menutup (membalut) tubuh dengan kain putih.

Dari paparan tersebut penulis ingin membuat suatu karya penciptaan foto yang terinspirasi dari buku karya Carl Gustav Jung yang berjudul Memories, Dreams, Reflections dan Hakikat di Balik Materi karya Harun Yahya sebagai sumber utama. Kedua buku tersebut mengatakan bahwa setiap manusia tidak bisa lepas dari masa lalu dan intensitas waktu. Waktu dikatakan sebagai persepsi yang ada di setiap manusia. Seperti yang dikatakan Francois Jacob dalam Yahya:

...Namun, di dunia seperti itu di mana waktu memiliki segisegi yang berlawanan, prosesproses di dalam otak kita dan cara memori kita mengumpulkan informasi, akan serupa itu pula fungsinya dengan berjalan. Hal 
yang sama juga berlaku bagi masa lalu dan masa depan dan dunia ini akan tampak bagi kita sama persis sebagaimana halnya yang tampak sekarang ini (Yahya, 2005:141).

Untuk mewujudkan karya foto ini, penulis menggunakan teknik fotografi potret dan studio agar mendapatkan hasil detail dari subjeknya. Subjek (model) dibalut dengan kain putih lalu peletakan pencahayaan (flash) dari samping subjek foto agar menimbulkan efek gelap terang yang kontras. Hasil pengambilan gambar tersebut diubah ke hitam putih. Karena dengan foto hitam putih, foto tersebut memiliki kemampuan untuk berdiri sendiri dan mempunyai kemampuan lebih untuk berkomunikasi secara visual. Dalam pembuatannya foto hitam putih lebih mementingkan komposisi, pencahayaan, perspektif, dan konteks (isi foto). Gaya foto yang akan penulis ciptakan akan bergaya surealis.

Tujuan dari penciptaan karya fotografi ini adalah menampilkan bahwa semua manusia tidak bisa lepas dari persepsi waktu, baik itu saat hidup maupun saat mati. "Waktu" selalu ada di mana pun manusia berada. Dengan melakukan eksplorasi dan melakukan berbagai eksperimen diharapkan karya yang diciptakan dapat memunculkan berbagai interpretasi bagi penikmatnya. Selain itu, diharapkan karya foto ini dapat memberi manfaat kepada penikmatnya agar dapat lebih positif dalam menjalani hidup.

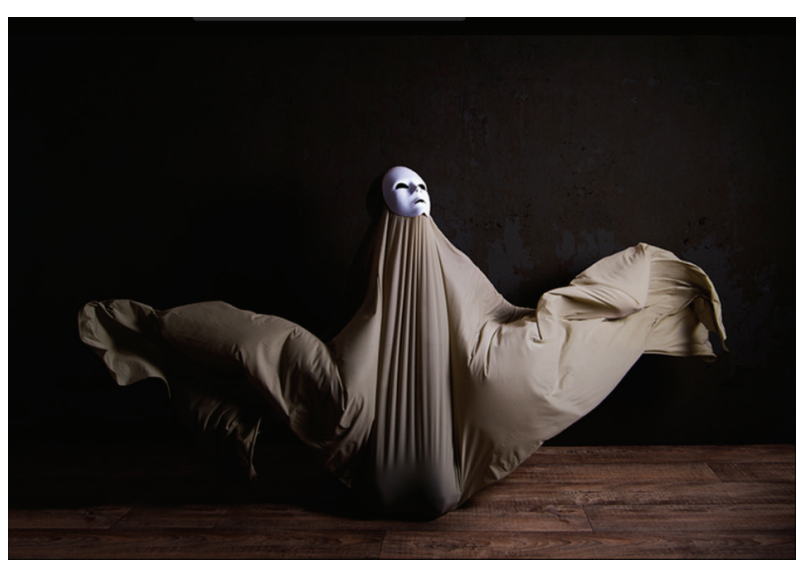

Gambar 1. Sphere Finder by Lotta van Droom

Tinjauan tema dan visual mutlak dilakukan untuk bahan komparasi serta mungkin juga sebagai referensi orisinalitas, bahkan dapat juga menjadi inspirasi. Setelah melakukan pencarian literatur dan pengumpulan informasi dari berbagai sumber didapatkan beberapa fotografer yang mempunyai kesamaan tema dan kesamaan visual dalam karya fotografinya. Akan tetapi, terdapat perbedaan yang signifikan dengan apa yang akan dikerjakan oleh penulis dan yang akan dijabarkan dengan contoh gambar karya yang juga akan disertakan.

Karya yang digunakan sebagai acuan adalah karya Lotta van Droom yang berjudul "Sphere Finder". Foto tersebut menggunakan model yang dibalut dengan kain sebagai media pendukungnya. Menggunakan pengambilan sudut pandang dengan komposisi horizontal dan tepat di tengah-tengah frame dan adanya background yang mendukung subjek agar terlihat lebih menonjol. Menggunakan satu cahaya bantu (flash) dari sebelah kiri dan diletakkan agak sedikit lebih tinggi daripada model untuk mendapatkan efek yang menonjolkan draperi (lipatan di kain).

Karya yang akan diciptakan oleh penulis sedikit banyak akan terinspirasi oleh Lotta van Droom, namun akan terdapat perbedaan yang signifikan dalam perwujudannya. Penulis akan 
mewujudkannya dengan warna hitam putih dan juga lebih menonjolkan ekspresi wajah model yang dibalut kain tersebut.

Pada tahapan proses kreatif, dalam hal ini yang akan dijabarkan adalah bagaimana proses kreatif perancangan dalam penciptaan fotografi. Hal ini terkait dengan tema yang menjadi bahasan, yaitu tentang "Waktu".

Waktu merupakan hal mutlak yang terjadi dalam setiap makhluk hidup dan waktu tersebut merupakan persepsi. Ruang dan waktu adalah bentuk-bentuk intuisi, yang tak dapat lagi dipisahkan darikesadaran daripada konsep-konsep kita atas warna, bentuk, atau ukuran (Yahya, 2005:143). Waktu tidaklah bersifat mutlak; ia adalah sebuah konsep subjektif yang ditangkap dan dirasakan secara beragam tergantung dari peristiwa-peristiwa yang dialami oleh manusia. Misalnya, pada saat ini sedang membaca sebuah buku dan sebelum itu memakan sesuatu di kantin, ada sebuah periode antara waktu kerika sedang makan sesuatu di kantin dengan saat ini. Hal inilah yang disebut dengan "waktu". Faktanya adalah saat sedang makan di kantin tadi merupakan sepotong informasi yang tersimpan di dalam memori otak. Perbandingannya, saat ini dengan informasi "makan di kantin" sebagai rentang waktu. Andaikata tidak membuat perbandingan ini, konsep tentang waktu pun tidak akan ada dan satu-satunya ke"saat"an yang ada adalah "saat ini” saja.

Karena otak kita bekerja dengan mengatur berbagai hal dalam sebuah urutan, kita berpikir bahwa waktu senantiasa berjalan maju. Akan tetapi, ini adalah sebuah keputusan yang dibuat otak kita dan dengan demikian sama sekali relatif sifatnya. Andaikata informasi di dalam otak kita diatur seperti sebuah film yang sedang diputar mundur, waktu pun bagi kita akan seperti film tersebut. Dalam situasi ini, kita akan berpikir bahwa masa lalu adalah masa depan dan masa depan adalah masa lalu (Yahya, 2005:141).

Dikarenakan sugesti-sugesti yang diterima, manusia berpikir bahwa hidup dalam pembagian waktu yang terpisah yang disebut masa lalu, masa kini, dan masa depan. Akan tetapi, satu-satunya alasan memiliki sebuah konsep "masa lalu" adalah karena berbagai hal yang telah dilalui tersimpan di dalam memori. Masa lalu merupakan salah satu pembentuk cara pandang dan cara berperilaku saat ini. Seperti yang diutarakan Jung (2003:237) bahwa sisasisa pengalaman masa lalu akan tetap ada di alam bawah sadar. Bentuk-bentuk dan muatanmuatan masa lampau masih menjadi milik kehidupan kita.

Selain itu, teori mengenai surealisme turut mendukung terciptanya karya fotografi ini. Surealisme merupakan gerakan seni yang mula-mula tumbuh di Eropa dan kemudian meluas secara internasional. Misteri tentang ketidaksadaran yang dihadapi para seniman seakan bertemu dengan wacana psikoanalisis yang dikembangkan Sigmund Freud. Estetika yang dikembangkan kaum Surealis berakar dari dadaisme yang antiseni yang mengungkapkan dunia khayal pada era sebelumnya. Gerakan surealisme banyak menggali gagasan tentang mimpi, ilusi, dan fantasi yang didorong otomatisme dan asosiasi bebas.

Menurut Breton:

"Surrealism is based on the belief in the superior reality of certain forms of previously neglected associations, in the omnipotence of dream, in the disinterested play of thought. It tends to ruin once and for all all other psychic mechanism and to substitute itself for them in solving all the principal problems of life" (Breton, 1969:26). 
Terdapat dua kecenderungan besar dalam perkembangannya, yakni ekspresif dan fotografis. Prinsipnya terdiri atas paduan keganjilan dan metamorfosis bentuk. Pengaruh gerakan ini menguat bukan hanya dalam seni rupa, melainkan juga dalam sastra, fotografi, teater, musik, film, iklan (desain grafis), dan mode.

Fotografi surealis atau surrealism photography merupakan gaya memotret dengan pendekatan-pendekatan kesenian. Membuat sebuah foto surrealism photography berarti menciptakan sebuah gambar yang melampaui aspek literal dari adegan atau subjek yang difoto. Ini berarti menciptakan gambar yang berupa visi pribadi, pesan, atau aspek metafora. Ini berarti menciptakan sebuah foto, bukan hanya mengambil foto. Foto surealis merupakan foto yang memang ditujukan untuk seni. Hal ini karena seni adalah kebalikan dari dokumentasi. Seni adalah ekspresi dari kepribadian, visi, dan inspirasi artis (dalam hal ini fotografer). Dengan demikian, sebuah foto seni adalah kendaraan fotografer untuk mewujudkan imajinasinya melalui foto. Oleh karena itu, harus dipertimbangkan seni sebuah foto bisa tidak murni dokumenter. Sebaliknya, foto jenis ini bersifat ekspresif. Ungkapan ini harus mencerminkan kepribadian, inspirasi, visi, gaya pribadi fotografer, dan yang paling penting, respons emosional dari fotografer itu sendiri. Foto itu tidak bisa hanya menunjukkan apa yang ada di depan kamera, ia juga harus menunjukkan apa yang fotografer rasakan. Sebuah foto seni selalu merupakan interpretasi dari data yang diambil ke dalam sebuah foto. Fotografi datang untuk menempati peran sentral dalam kegiatan surealis. Dalam karya-karya Man Ray dan Maurice Tabard, penggunaan prosedur seperti paparan ganda, printing kombinasi, montase, dan solarisasi dramatis membangkitkan persatuan mimpi dan kenyataan fotografer itu sendiri.

Menurut Thomas Munro dalam Soedarso (2006:68): "Seni adalah alat buatan manusia untuk menimbulkan efek-efek psikologis atas manusia lain yang melihatnya. Efek tersebut mencakup tanggapan-tanggapan hasil dari pengamatan, pengenalan, imajinasi, baik yang rasional maupun emosional".

Dari pemikiran Munro tersebut, seni harus dapat menimbulkan efek-efek psikologis yang merespons emosional dan menimbulkan sensasi-sensasi yang berbeda. Dengan kata lain, karya seni haruslah mempunyai pesan yang tidak saja harus tersampaikan namun juga dapat memengaruhi psikologis atau respons emosional dari penikmatnya.

Dalam penciptaan fotografi ini, penulis menggunakan foto hitam putih. Menurut Sontag (2005:100) dalam bukunya On Photography: "Another instance: many photographers continue to prefer black-and-white images, which are felt to be more tactful, more decorous thancolor-orless voyeuristic and less sentimental or crudely lifelike. But the real basisfor this preference is, once again, an implicit comparison with painting”.

\section{LANDASAN PENCIPTAAN}

Dalam fotografi cahaya merupakan hal yang penting karena seorang fotografer bisa disebut sebagai seorang pelukis cahaya. Jadi, bisa dikatakan bahwa cahaya merupakan hal yang terpenting dalam perannya untuk menciptakan sebuah karya fotografi. Istilah fotografi sendiri dipopulerkan Sir John Herschel (The Visual Dictionary of Photography) pada tahun 1839 di Prancis dan Inggris.

Fotografi sejak ditemukan telah mengalami perubahan besar baik dari teknologi, 
kegunaan, maupun makna kehadirannya. Dari tujuan semula sebagai alat bantu melukis, fotografi kemudian mempunyai bentuk dan kemampuan tersendiri dalam membuat gambar. Pada abad ke-19 fotografi melesat menjadi salah satu penemuan yang paling banyak berkontribusi pada zaman revolusi industri dan menguasai dunia melalui industri percetakan hingga dimulainya ekspansi teknologi televisi dan video. Hingga saat ini fotografi masih diperhitungkan kehadirannya dengan bentuk dan format baru (digital).

Fotografi masih dipakai sebagai media dengan berbagai macam tujuan termasuk seni. Menurut Feininger dalam Soelarko (1999:41): "Napsu untuk mencipta ialah dasar bagi semua juru foto yang besar keinginan mencoba lagi, guna mencapai kesempurnaan, tiap kali mengharapkan untuk mendekati yang telah dibayangkan dalam pikiran.

Dengan kata lain, eksplorasi mendekatkan penulis pada kesempurnaan visualisasi ide eksplorasi dan juga dapat membuat penulis menemukan tata cara yang lebih baik serta efektif dan efesien dalam mencapai karya seni yang ideal bahkan sangat mungkin menemukan sesuatu yang baru. Perwujudan karya fotografi ini dengan subject manusia adalah bentuk eksplorasi yang dilakukan oleh penulis. Subjek manusia yang dibalut dengan kain yang merepresentasikan waktu, diharapkan dapat mengakomodasi ide penullis dalam menciptakan karya seni fotografi yang baru.

Sebuah kenyataan yang dirasakan oleh Bruce Barnbaum yang juga dirasakan oleh penulis, bahwa realisme yang melekat pada fotografi membuatnya menjadi genre seni yang paling kuat didunia saat ini. Ia mengungkapkan:

In the first chapter, Idiscussed my feeling that photography's inherent realism $m a k e s$ it the most powerful art form in theworld tiday. People generally view a photograph as a literal depiction of reality, even when the image is highly manipulated. This gives the photographer the power to alter reality greatly and still present it as reality, a power that no other art form possesses (Barnbaum, 2010:299).

Orang biasanya melihat sebuah foto sebagai gambaran harfiah dari realitas, bahkan ketika gambar tersebut sangat dimanipulasi. Hal ini memberikan fotografer kekuatan untuk mengubah realitas dengan sangat masif dan masih hadir sebagai realitas, kekuatan yang tidak dimiliki oleh genre yang lainnya. Karena itu seperti yang dikatakan oleh Howard S. Becker dalam Berger (2000:139):

Ketika seseorang membuat atau menggunakan foto untuk tujuan ilmiah atau studi, mereka tidak berusaha demi sudut pandang yang unik atau model pribadi. Sebaliknya, mereka ingin menggunakan alat yang membantu mereka menjawab suat pertanyaan yang secara serius dikaitkan dengan komunitas yang memperhatikan pertanyaan semacam itu. Foto semacam itu jarang dibuat dengan suatu model standar, agar dapat diterima dalam komunitas pemakai sehingga masyarakat mengira bahwa itulah satu-satunya cara gambar semacam itu dibuat. Namun setiap pilihan telah terwujud dalam kesan itu ---- pemberian bingkai, penempatan lensa, lampu, dan teknik pencetakan --- merupakan suatu pilihan yang seharusnya dibuat secara berbeda, dengan suatu foto yang berbeda pula.

Becker (2000:139) menujukkan bahwa semuanya itu merupakan jenis keputusan 
estetika untuk dilakukan bahkan dalam pengambilan gambar yang terus-menerus. Kamera tidak bekerja dengan sendirinya, atau seperti yang ditulis Becker, "foto tidak merekam kenyataan secara alami”.

Gagasan bahwa kamera hanya memantulkan suatu realita merupakan pertanggungjawaban atas dugaan banyak orang yang mengatakan bahwa televisi selalu menampilkan kebenaran. Masyarakat percaya pada hal tersebut karena seperti yang dikatakan oleh semua orang bahwa "penglihatan adalah kepercayaan". Hal yang tidak dipikirkan masyarakat dan hal ini diterapkan secara sama pada gambar fragmen foto adalah bahwa apa yang mereka lihat di kamera tidak lebih penting daripada menampilkan apa yang sebenarnya terjadi. Kamera selalu merekam sudut pandang orang penting atau pandangan yang bisa saja merupakan bagian dari kebenaran, tetapi bukan kebenaran sepenuhnya.

Selanjutnya apa yang dikemukakan oleh Soedjono (2007:102) bahwa suatu foto agar menjadi karya seni haruslah dapat mewakili keinginan sang seniman; tanpa harus menyampingkan faktor-faktor teknis yang ada, suatu objek haruslah disikapi dan 'dibumbui' dengan nilai subjektif si fotografer agar menjadi suatu karya seni. Kamera, teknik, proses, dan objek menjadi bahan ramuan bagi seorang seniman foografer untuk 'memaksakan' menjadi suatu 'sajian' yang sesuai dengan konsep dan ekspresi senimannya.

Komposisi dan pengaturan sudut pandang bukan saja sebagai "bumbu" penyedap yang harus ditambahkan, tetapi sebagai unsur penting dalam pencapaian visualisasi gagasan dalam bentuk karya fotografi ekspresi yang sesuai dengan ekspresi, fantasi, dan konsep sang seniman. Hal yang paling diperhatikan atau bahkan salah satu unsur terpenting dalam penciptaan karya fotografi ini adalah komposisi, seperti yang disinggung oleh Clark (2011:280): The first step to creating fine art is finding subject matter that's interesting to you. If you catches your eye in real life, you should be able to compose a beautiful image of it is a fine art photography has a sense of poetry: The shapes, lines, tones, and lighting work together to provide an image that needs no explanation. Viewers easily can feel something when looking at a understanding of its intended message.

Langkah pertama untuk menciptakan seni rupa adalah menemukan subjek yang menarik perhatian. Jika dapat menarik perhatian saat melihat secara langsung, maka bisa membuat sebuah komposisi karya seni rupa yang indah. Komposisi juga merupakan hal yang penting. Komposisi yang sukses dalam fotografi seni rupa adalah yang memiliki jiwa puisi: bentuk, garis, nada, dan pencahayaan yang bekerja sama untuk membuat gambar yang tidak perlu memerlukan penjelasan. Pemirsa dengan mudah dapat merasakan sesuatu ketika melihat gambar yang terkomposisi dengan baik; yang selanjutnya akan membawa pemirsa untuk memerhatikan lebih dalam dan mendapatkan pemahaman yang lebih baik dari pesan yang dimaksudkan.

\section{METODE PENCIPTAAN}

Ada banyak cara seseorang mendapatkan ide gagasan, biasanya ide timbul dari sering melihat-lihat yang sering disukai dan ingin diekspresikan dalam bentuk seni. Seni adalah cara seseorang mengekspresikan ide yang ada di dalam pikiran dan disampaikan kemudian hasil jadinya berupa karya seni. Semakin banyak seseorang mempunyai pengetahuan, semakin banyak pula keresahan pikiran yang membebaninya. Sebaliknya, semakin banyak 
referensi yang dimiliki oleh seseorang, semakin mudah bagi orang tersebut menemukan ide gagasan untuk menuangkannya menjadi sebuah karya seni. Seperti halnya penulis terinspirasi oleh buku Memories, Dreams, Reflections dan Hakikat di Balik Materi yang membahas konsepsi waktu dan pengalaman manusia. Dari kedua buku tersebut timbullah keresahan pikiran yang kemudian dituangkan menjadi suatu karya seni fotografi. Berbekal dari referensi dari beberapa seniman yang menjadi inspirasi, kemudian penulis mencari literatur lain sebagai tambahan referensi dan juga sebagai bahan pengujian orisinalitas, tambahan ide sekaligus menjadi landasan yang memperkuat pemaknaan dan perwujudan karya seni fotografi yang akan dibuat.

Eksplorasi dilakukan sejak awal terbentuknya gagasan hingga proses perwujudan. Setiap langkah pengumpulan referensi adalah eksplorasi, demikian juga langkah demi langkah menuju perwujudan adalah bagian eksplorasi. Pencarian ide terus berlanjut, mencari kemungkinan yang terbaik dalam hal perwujudan juga terus dilakukan di samping mencari materi terbaik yang akan dipakai sebagai objek yang akan ditampilkan.

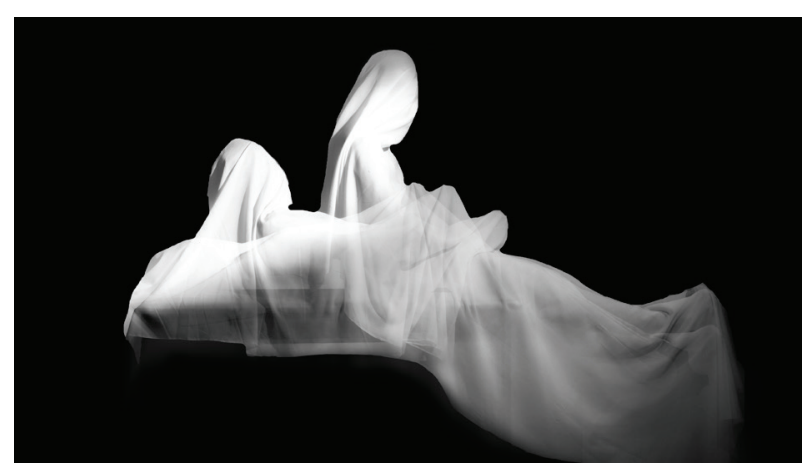

Gambar 2. Re-Alive (eksplorasi dengan menggunakan teknik multiple exposure dengan manusia sebagai subjeknya)

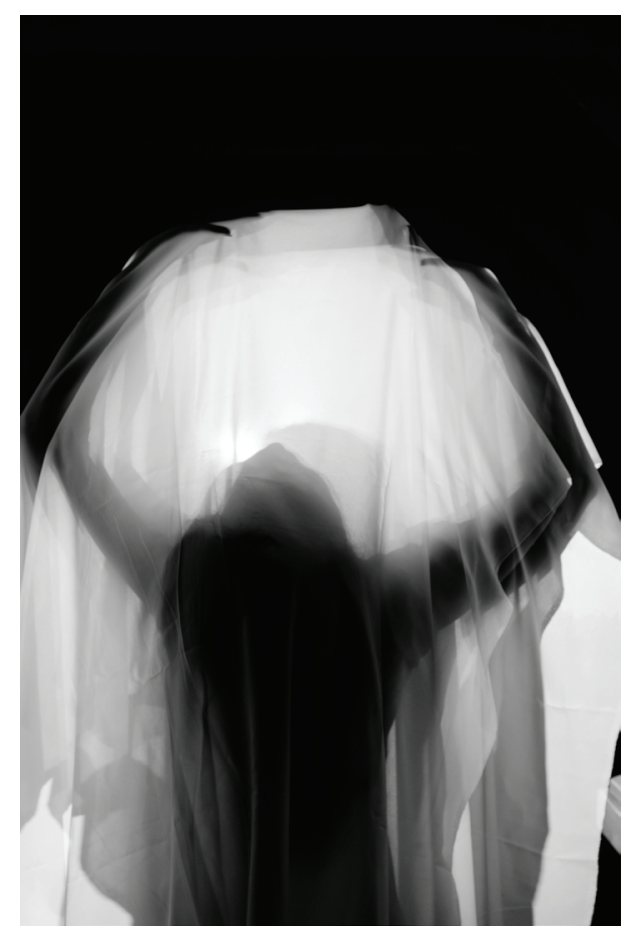

Gambar 3. Free Me! (eksplorasi dengan menggunakan teknik backlighting)

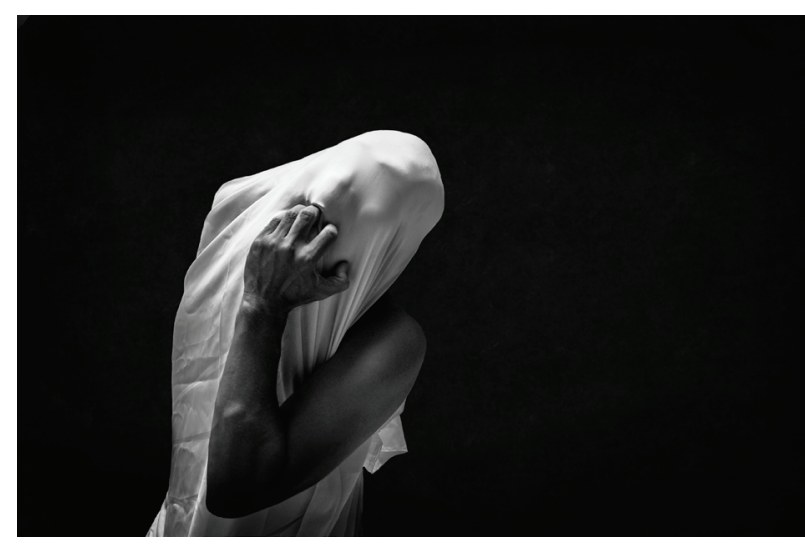

Gambar 4. Let Me Free!! (eksplorasi dengan menggunakan teknik side lighting yang mengutamakan ekspresi subjek)

Penulis mencoba melakukan eksplorasi dengan mecoba menggunakan objek manusia yang dibalut kain dengan menggunakan teknik multiple exposure agar mendapatkan kesan pergerakan dari subjeknya.

Eksplorasi selanjutnya penulis menggunakan flash yang diletakkan di belakang model. Hal ini dimaksudkan agar memberikan kesan siluet yang hanya memperlihatkan kontur dari subjeknya (model). 
Selanjutnya, penulisjugamengeksplorasi subjek dengan menggunakan side lighting (cahaya samping) yang akan memberikan kontras bayangan dan juga draperi yang lebih menonjol. Dalam eksplorasi ini, penguatan akan ekspresi subjek lebih diutamakan agar menimbulkan kesan ketidakberdayaan manusia untuk lepas dari genggaman sang waktu (yang direpresentasikan dengan kain putih). Dari hasil eksplorasi ini penulis mendapatkan pengalaman yang menarik dan diharapkan adanya daya ganggu dan daya pukau yang terdapat pada ekspresi subjek diharapkan juga memengaruhi emosional penikmatnya.

Perwujudan objek dimulai dari perwujudan ide menjadi visual sketsa kasar yang kemudian dilanjutkan dengan mengidentifikasi bahan-bahan apa saja yang akan dipakai sebagai unsur terciptanya karya fotografi seni ini. Selanjutnya menyediakan tempat pemotretan yang memadai. Pemotretan dilakukan dengan menggunakan kamera DSLR APS-C merk Nikon D7000 dan menggunakan lensa Tamron 17-50 f 2.8 VC SP dibantu dengan tripod dan peralatan lainya seperti trigger sebagai alat pemicu flash dan shutter release untuk mengendalikan kamera secara eksternal. Lalu penulis mulai mengatur sudut pengambilan gambar dan peletakan flash agar kesan yang ditampilkan lebih dramatis dan ekspresi dari subjek lebih terlihat menonjol disertai dengan gestur-gestur badan untuk lebih menguatkan kesan yang akan disampaikan. Semua pemotretan dilakukan outdoor pada malam hari.

Proses penyuntingan foto dilakukan menggunakan komputer dengan bantuan perangkat lunak penyunting Adobe Photoshop dan Adobe Lightroom. Dalam proses penyuntingan lebih diutamakan hanya sekadar perbaikan komposisi (cropping), mengubah menjadi foto hitam putih, pengaturan gelap terang, serta penyesuaian background agar hasil akhirnya sesuai dengan yang diharapkan.

\section{ULASAN KARYA}

Dari proses perwujudan dan eksplorasi yang sudah dijelaskan, tercipta tujuh karya "Beyond Time". Ulasan karya ini diharapkan dapat menjadi bahan tambahan pembaca tentang maksud dan tujuan yang tertuang dalam foto tersebut. Pembahasan lebih dititikberatkan pada makna foto dan bukan pada teknis pembuatannya yang rata-rata mempunyai teknis yang hampir sama. Membaca foto memberikan pengalaman yang berbeda dengan membaca buku atau tulisan. Saat membaca buku dan tulisan, otak kiri terstimulus oleh pengalaman bahasa yang dimengerti. Kemudian memicu otak untuk membayangkan atau menggambarkan sesuatu yang disebut dalam tulisan tersebut, sebaliknya ketika seseorang melihat visual (gambar), otak dan pikiran akan mencoba untuk mengidentifikasi elemen apa yang ada pada gambar tersebut menjadi satu bentuk bahasa yang dimengerti atau memunculkan persepsi serta interpretasi baru yang sesuai dengan pengalaman yang dialami oleh orang (penikmat) tersebut. Dengan menyajikan ulasan makna foto diharapkan pembaca ataupun penikmat foto dapat merasakan pengalaman baru dalam memahami arti sebuah foto, seperti foto konseptual yang mempunyai makna yang dibuat untuk disampaikan menggunakan media fotografi. 


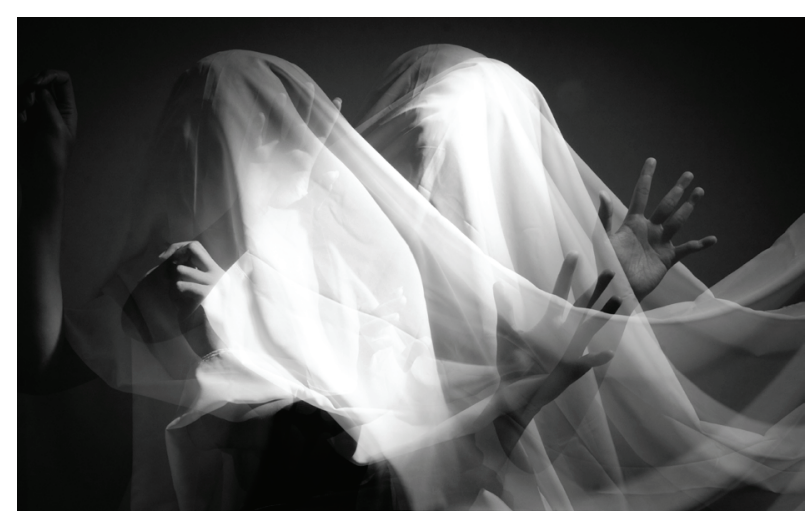

Karya 1. Blind

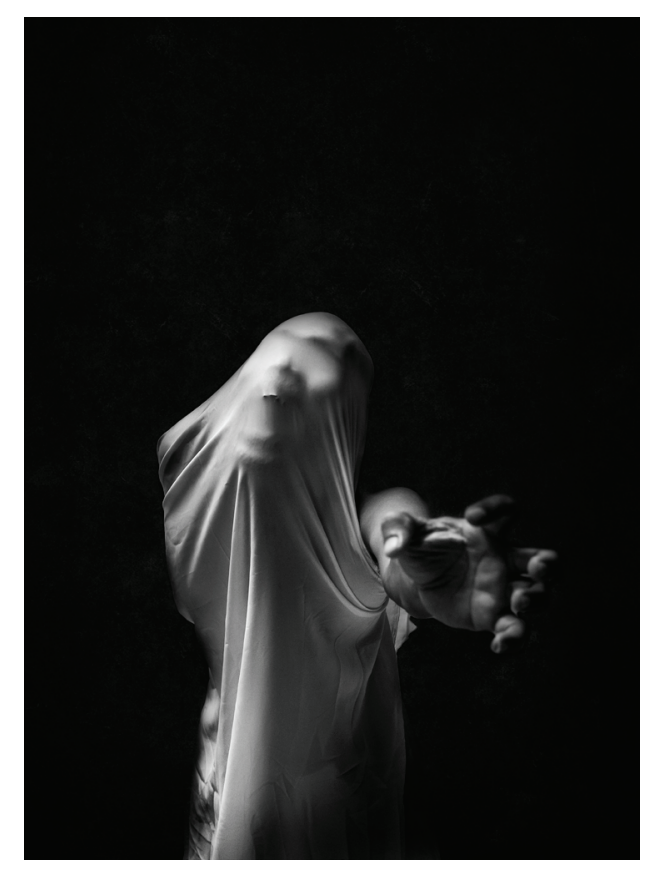

Karya 2. Let Me Free

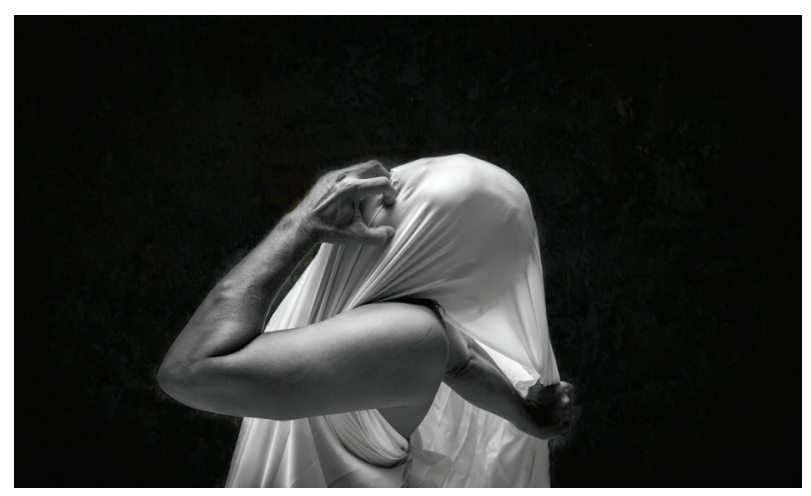

Karya 3. Let Me Free \#2

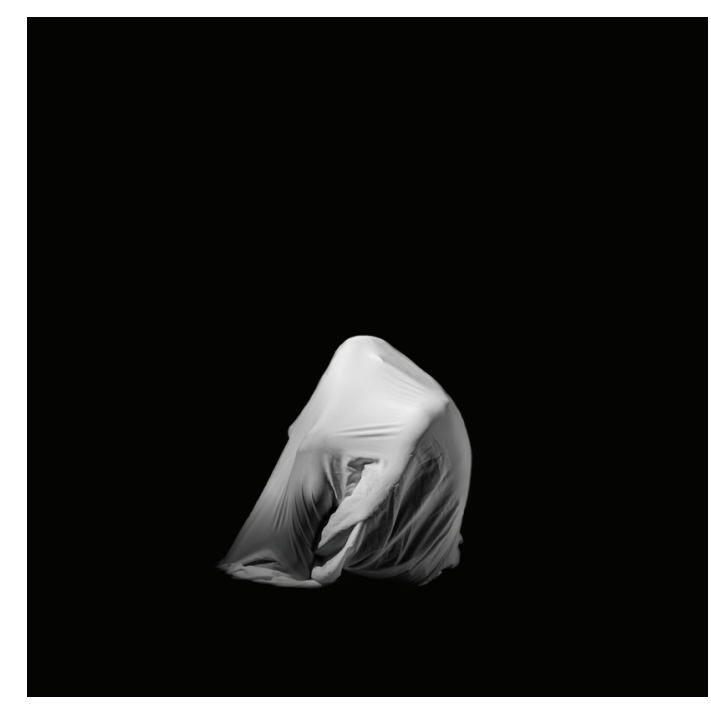

Karya 4. Lahir

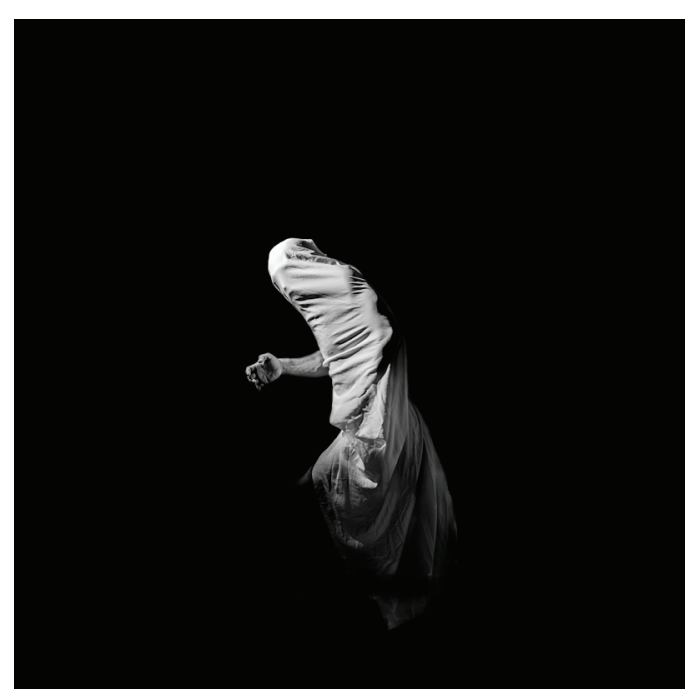

Karya 5. Muda

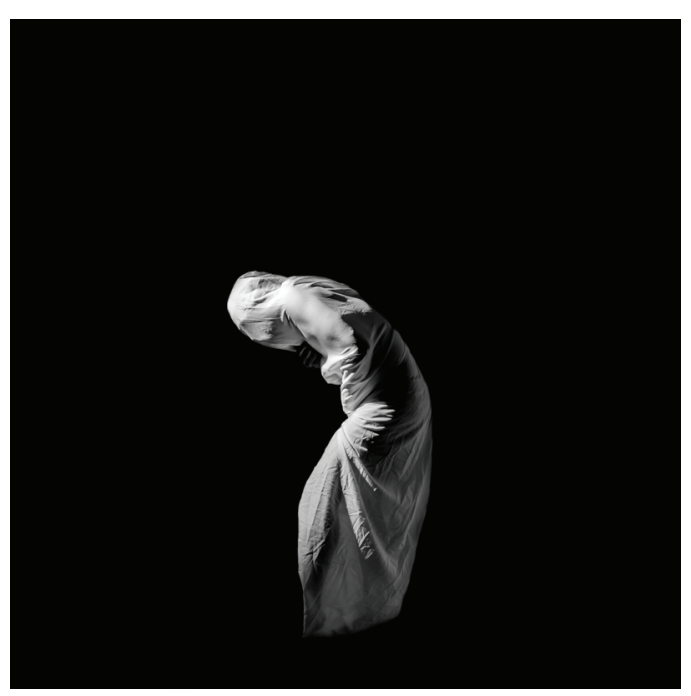

Karya 6. Tua 


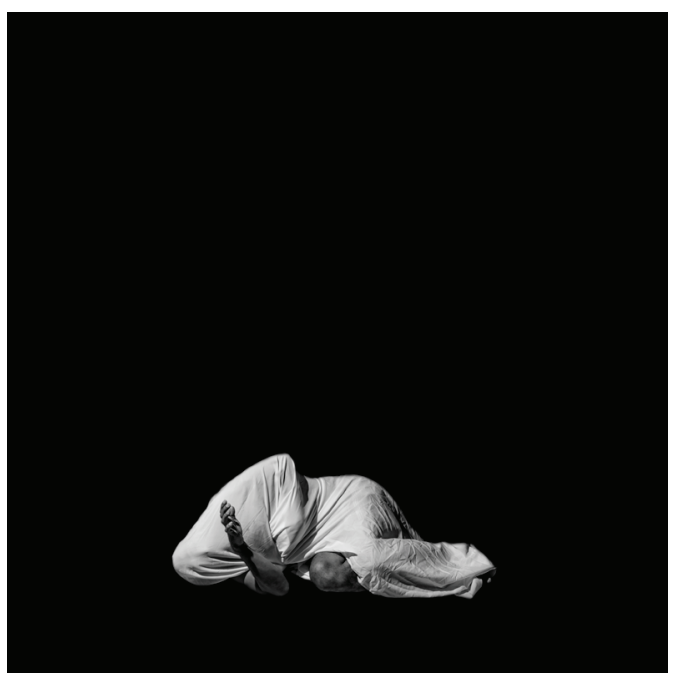

Karya 7. Mati

Karya pertama berjudul Blind bercerita tentang seseorang yang tidak tahu arah dan tujuan hidup. Teknik multiple exposure digunakan agar menghasilkan efek gerakan dan juga terlihat seperti dua orang.

Karya Let Me Free bercerita bahwa setiap orang mustahil terlepas dari "waktu". Meskipun sekuat apa pun untuk tidak memedulikannya, realitas yang terjadi pada setiap manusia tidak bisa dipungkiri. Kenyataan bahwa setiap orang menua dan akhirnya mati, membuat sebagian orang takut untuk menghadapinya. Masa lalu dan masa depan merupakan rahasia waktu yang hanya Tuhan yang mengetahuinya.

Ketujuh karya tersebut bercerita mengenai siklus kehidupan manusia. Dari masih di dalam kandungan hingga terlahir ke dunia, menjadi muda dan bekerja, lalu menjadi tua dan lemah, hingga manusia itu mati. Konsep tersebut penulis tampilkan dengan mencoba membuat photo sequence.

\section{SIMPULAN}

Setelah melakukan pengenalan, eksplorasi, pendalaman, dan visualisasi karya mengenai "waktu", penulis sadar masih banyak kekurangan dalam mengeksplorasi karya.
Perancangan ini berupaya menyampaikan pesan kepada masyakat untuk menggugah dan merenungkan kembali makna dan arti kehidupan, bahwasa waktu yang dianggap lama, ternyata amatlah singkat dalam "kewaktuan" Ilahiah. Media foto merupakan media yang sangat tepat dalam menggambarkannya karena orang cenderung lebih mengingat kesan visual daripada kesan tulisan.

\section{KEPUSTAKAAN}

Barnbaum, Bruce. 2010. The Art of Photography: An Approach to Personal Expresion. California: Rocky Nook Inc.

Berger, Arthur Asa. 2000. Tanda-Tanda dalam Kebudayaan Kontemporer.

Yogyakarta: Tiara Wacana Yogya.

Breton, Andre. 1969. Manifestoes of Surrealism.

Michigan: The University of Michigan Press.

Clark, Tom. 2011. Digital Photography Composition for Dummies. Indiana: Wiley Publishing, Inc.

Feiniger, Andreas. 1965. The Complete Photographer (Unsur-Unsur Utama Fotografi). Terjemahan R.M. Soelarko. 1999). Semarang: Dahara Publishing.

Grant, Kim. 2005. Surrealism and The Visual Arts. UK: Cambridge University Press.

Jung, Carl Gustav. 2003. Memories, Dreams, Reflections. Yogyakarta: Penerbit Jendela.

Prakel, David. 2010. The Visual Dictionary of Photography. UK: AVA Publishing.

Soedarso, SP. 2000. Sejarah Seni Rupa Modern. Yogyakarta: Penerbit ISI.

Soedarso, SP. 2006. Trilogi Seni: Penciptaan, Estetika, dan Kegunaan Seni. Yogyakarta: BP ISI Yogyakarta. 
Soedjono, Soeprapto. 2007. Pot-Pourri

Fotografi. Jakarta: Universitas Trisakti.

Sontag, Susan. 2005. On Photography. New York: Rosetta Book.

Wolmen, Benjamin B. 1981. Contemporary

Theories and Systems in Psychology.

New York.N.Y.10011.

Yahya, Harun. 2005. Hakikat di Balik Materi.

Surabaya: Risalah Gusti. 